\title{
Ecology of neotropical mistletoes: an important canopy-dwelling component of Brazilian ecosystems
}

Rafael Arruda ${ }^{1,9}$, Rodrigo Ferreira Fadini ${ }^{2}$, Lucélia Nobre Carvalho ${ }^{1}$, Kleber Del-Claro ${ }^{3}$, Fabiana Alves Mourão ${ }^{4}$, Claudia Maria Jacobi ${ }^{4}$, Grazielle Sales Teodoro ${ }^{5}$, Eduardo van den Berg ${ }^{6}$, Claudenir Simões Caires ${ }^{7}$ and Greta Aline Dettke ${ }^{8}$

Recebido em 28/09/2011. Aceito em 9/04/2012

\begin{abstract}
RESUMO
(Ecologia de ervas-de-passarinho Neotropicais: um importante componente do dossel de ecossistemas brasileiros). Ervas-de-passarinho têm sim sido regularmente estudadas em países temperados por afetar negativamente espécies cultivadas e florestas manejadas. Em comparação com ambientes temperados pouco se conhece sobre a ecologia das ervas-de-passarinho neotropicais. Desta forma, é necessário maior conhecimento sobre o grupo porque são importantes elementos de comunidades vegetais, atuando como recurso-chave para polinizadores, dispersores de sementes e herbívoros. Através de uma combinação de trabalhos clássicos já publicados com evidências empíricas recentes, nós apresentamos padrões emergentes da interação entre ervas-de-passarinho com os organismos associados e questionamentos para estudos adicionais. Existe um crescente interesse neste grupo no Brasil. E embora existam informações sobre dispersão de sementes, estudos sobre biologia reprodutiva são raros e representam um campo a ser explorado. O conhecimento da biologia básica das ervas-de-passarinho será relevante para modelar sua distribuição espacial usando uma abordagem metapopulacional ou epidemiológica. Nesta revisão nós sumarizamos os principais estudos conduzidos na região Neotropical para fornecer um panorama atual das pesquisas desenvolvidas, bem como novas ideias para futuras investigações, especialmente no Brasil.
\end{abstract}

Palavras-chave: Hemiparasitas, biologia da conservação, especificidade por hospedeiros, compatibilidade por hospedeiros

\begin{abstract}
(Ecology of neotropical mistletoes: an important canopy-dwelling component of Brazilian ecosystems). Mistletoes have been studied in temperate countries regularly because they can be pests of cultivated plants and forest plantations. In comparison with temperate habitats, little is known about the ecology of mistletoes in the Neotropics. More emphasis should be given to neotropical mistletoes because they could be important elements of plant communities, acting as key resources for pollinators, seed dispersers and herbivores. Using a combination of findings from early mistletoe studies and empirical evidence from several recent case studies, we report emerging patterns of mistletoe interactions with associated organisms and propose aims for further studies. There has been increasing interest in working with mistletoes in Brazil. Although there are some data on the ecology of mistletoe seed dispersal, reproductive biology studies are scarce and represent a wide range of fieldwork to be explored. Knowledge of the basic biology of mistletoes will be very important for modeling their spatial distribution using metapopulation or epidemiological approaches. In this review, we summarize the studies conducted in the neotropical region in order to provide a framework for current research and new ideas for future investigations of mistletoes, especially in Brazil.
\end{abstract}

Key words: Hemiparasites, biological conservation, host specificity, host compatibility

\footnotetext{
Universidade Federal de Mato Grosso, Instituto de Ciências Naturais, Humanas e Sociais, Sinop, MT, Brasil

2 Universidade Federal do Oeste do Pará, Instituto de Biodiversidade e Florestas, Santarém, PA, Brasil

3 Universidade Federal de Uberlândia, Instituto de Biologia, Uberlândia, MG, Brasil

4 Universidade Federal de Minas Gerais, Instituto de Ciências Biológicas, Departamento de Biologia Geral, Belo Horizonte, MG, Brasil

5 Universidade Estadual de Campinas, Instituto de Biologia, Departamento de Botânica, Campinas, SP, Brasil

6 Universidade Federal de Lavras, Departamento de Biologia, Setor de Ecologia, Lavras, MG, Brasil

7 Universidade de Brasília, Instituto de Ciências Biológicas, Departamento de Botânica, Campus Darcy Ribeiro, Brasilia, DF, Brasil

8 Universidade Federal do Rio Grande do Sul, Instituto de Biociências, Departamento de Botânica, Laboratório de Fitoecologia e Fitogeografia, Porto Alegre, RS, Brasil

9 Author for correspondence: rafael.arruda@pq.cnpq.br
} 


\section{Introduction}

Mistletoes are shoot parasites of plant species (Kuijt 1969; Calder \& Bernhardt 1983; Press \& Grave 1995; Norton \& Carpenter 1998; Watson 2001; Mathiasen et al. 2008; Arruda et al. 2009). The majority of mistletoes are hemiparasites (partially parasitic), presenting leaves and producing their own photoassimilates, while obtaining water and nutrients through their haustoria (Kuijt 1969; Calder \& Bernhardt 1983; Kuijt 2009). Hemiparasite species parasitize the xylem of their hosts, while holoparasites (totally parasitic) are phloem parasites (Kuijt 1969; Calder \& Bernhardt 1983; Kuijt 2009). Although there is a vast body of literature on mistletoes, little is known about their natural history and ecology in the Neotropics (Mathiasen et al. 2008; Arruda et al. 2009).

The natural history and ecology of mistletoes have been studied regularly in temperate countries because they are pests to cultivated plants and forest plantations (Norton \& Carpenter 1998; Mathiasen et al. 2008; Arruda et al. 2009). Preliminary investigations aimed to quantify the effects of mistletoe presence on host growth and to describe the processes of seed dispersal and seedling establishment (e.g., Hudler et al. 1979; Calder \& Bernhardt 1983; Thomson \& Mahall 1983; Davidar 1987). Further studies focused on germination ecology and the range of hosts used by mistletoes (Kuijt 1969; Calder \& Bernhardt 1983; Downey 1998). In Brazil, the first studies on mistletoes described the morphological and anatomical characteristics of three loranthaceous species: Struthanthus vulgaris Mart. ex Eichl. (Venturelli 1981; Venturelli 1984a; Venturelli \& Kraus 1989), S. flexicaulis (Mart. ex Schult. f.) Mart. (Venturelli 1984b) and Tripodanthus acutifolius (Ruiz \& Pav.) Tiegh. (Forstreuter 1988; Forstreuter \& Weber 1991). Ecological studies were initiated a decade later by Monteiro et al. (1992).

Although mistletoes can cause an impact on reproduction and growth of their hosts, they may also act as keystone resources and structures in forest ecosystems (Watson 2001). Despite the fact that a diverse assemblage of mistletoes exists in the Neotropics, both basic and applied studies are still incipient as compared to countries such as the United States, New Zealand and Australia (Norton \& Reid 1997; Watson 2001). According to Mathiasen et al. (2008), mistletoes are investigated in three lines of research. The first is the study of mistletoes' effects on wildlife, mainly on their role as nesting sites for birds (e.g., Cooney et al. 2006; Barea 2008; Cooney \& Watson 2008) (Fig. 1). The second explores the role of mistletoes as a food resource for groups of organisms, including pollinators (e.g., Barros et al. 2001; Azpeitia \& Lara 2006), seed dispersers (e.g., López de Buen \& Ornelas 1999; Carlo \& Aukema 2005) and herbivores (e.g., Guerra et al. in press). The last approach is directed towards understanding interactions between mistletoes and their environment, which seeks to determine the influence of mistletoes on the composition of plants and animals via their modification of vertical and horizontal vegetation structures, water uptake and plant succession (March \& Watson 2007; 2010).

In this paper, we present a brief review of the mistletoe group by focusing on studies conducted in the neotropical region, mainly in Brazilian biomes. Since we are authors of most of mistletoe papers presented to Brazil, the themes of this work will probably be biased towards the studies that we have conducted. Therefore, this work is not an exhaustive review, but rather provides a framework for the current research on mistletoes in Brazil and serves as a starting point for new investigations.

\section{Taxonomic relationships, diversity and distribution of mistletoes in Brazil}

Mistletoes belong to the Santalales order, which has 18 families: Amphorogynaceae, Aptandraceae, Cervantesiaceae, Comandraceae, Coulaceae, Erythropalaceae, Loranthaceae, Misodendraceae, Nanodeaceae, Octoknemaceae, Olacaceae, Opiliaceae, Santalaceae, Shoepfiaceae, Strombosiaceae, Thesiaceae, Viscaceae and Ximeniaceae (Nickrent et al. 2010). Of these, only Amphorogynaceae, Comandraceae, Misodendraceae, Nanodeaceae and Octoknemaceae are not present in Brazil (Caires \& Dettke 2010a, b; Hiepko 2010; Rossi (2010) (Tab. 1).

Recent molecular phylogenetic studies have added 13 families to the order; four of these are new to science and were formerly included in Santalaceae s.l.: Amphorogynaceae, Cervantesiaceae, Comandraceae, and Nanodeaceae. Eremolepidaceae is now included in Santalaceae, and Viscaceae is recognised as a distinct family (Nickrent et al. 2010). Mistletoes are found in five families of Santalales: Amphorogynaceae, Loranthaceae, Misodendraceae, Santalaceae and Viscaceae. These families do not form a monophyletic group, suggesting that parasitism of aerial branches evolved multiple times throughout the evolution of Santalales (Vidal-Russell \& Nickrent 2008).

In the Brazilian flora, the only mistletoe families are the Loranthaceae, Santalaceae and Viscaceae, which collectively comprise 203 species. The family Loranthaceae is the most representative in terms of number of genera and species (Kuijt 2009; Caires \& Dettke 2010a, b) (Tab. 1, Fig. 1). A large diversity of mistletoe species occurs in forests, although Cerrado (savanna vegetation) is better studied (Arruda et al. 2009).

Loranthaceae have a close relationship with the clade comprising Schoepfiaceae (a group that includes tropical arboreal species as well as temperate herbs and shrubs) and Misodendraceae (mistletoe species endemic to a Nothophagus forest on the Chilean coast). The family has a pantropical distribution and comprises 73 genera and 800 species. The Brazilian flora contains 12 genera and 131 spe- 
Rafael Arruda, Rodrigo Ferreira Fadini, Lucélia Nobre Carvalho, Kleber Del-Claro, Fabiana Alves Mourão, Claudia Maria Jacobi, Grazielle Sales Teodoro, Eduardo van den Berg, Claudenir Simões Caires and Greta Aline Dettke

Table 1. Richness of taxa and plant life-form of Santalales occurring in Brazil. * unpublished, ${ }^{* *}$ in revision.

\begin{tabular}{|c|c|c|c|}
\hline Families & Genera & BR spp. / W spp. & Plant life-form \\
\hline \multirow[t]{3}{*}{ Aptandraceae } & Aptandra & $2 / 4$ & Shrubs or Trees \\
\hline & Cathedra & $5 / 5$ & Shrubs or Trees \\
\hline & Chaunochiton & $3 / 3$ & Trees \\
\hline \multirow[t]{2}{*}{ Cervantesiaceae } & Acanthosyris & $3 / 6$ & Shrubs or Trees \\
\hline & Jodina & $1 / 1$ & Trees \\
\hline Coulaceae & Minquartia & $1 / 1$ & Trees \\
\hline Erythropalaceae & Heisteria & $21 / 34$ & Lianas, Shrubs or Trees \\
\hline \multirow[t]{12}{*}{ Loranthaceae } & Cladocolea & $3 / 30$ & Mistletoes \\
\hline & Gaiadendron & $1 / 1$ & Mistletoes \\
\hline & Phthirusa & $2 / 7$ & Mistletoes \\
\hline & Ligaria & $2 / 2$ & Mistletoes \\
\hline & Oryctanthus & $4 / 11$ & Mistletoes \\
\hline & Oryctina & $3^{*} / 3^{*}$ & Mistletoes \\
\hline & Passovia & $15^{* *} / 22^{* *}$ & Mistletoes \\
\hline & Peristethium & $1 / 7^{* *}$ & Mistletoes \\
\hline & Psittacanthus & $42 / 119$ & Mistletoes \\
\hline & Pusillanthus & $1 / 1$ & Mistletoes \\
\hline & Struthanthus & 56/ca. 60 & Mistletoes \\
\hline & Tripodanthus & $1 / 3$ & Mistletoes \\
\hline \multirow[t]{2}{*}{ Olacaceae } & Dulacia & $10 / 13$ & Shrubs or Trees \\
\hline & Ptychopetalum & $2 / 5$ & Shrubs or Trees \\
\hline Opiliaceae & Agonandra & $5 / 10$ & Trees \\
\hline \multirow[t]{2}{*}{ Santalaceae } & Antidaphne & $4 / 9$ & Mistletoes \\
\hline & Eubrachion & $1 / 2$ & Mistletoes \\
\hline \multirow[t]{2}{*}{ Schoepfiaceae } & Arjona & $1 / 10$ & Terrestrial herbs \\
\hline & Schoepfia & $3 / 25$ & Shrubs or Trees \\
\hline Strombosiaceae & Tetrastylidium & $2 / 2$ & Shrubs or Trees \\
\hline Thesiaceae & Thesium & $2 / 350$ & Terrestrial herbs \\
\hline \multirow[t]{2}{*}{ Viscaceae } & Dendrophthora & 3/ca. 124 & Mistletoes \\
\hline & Phoradendron & $64 / 237$ & Mistletoes \\
\hline \multirow[t]{3}{*}{ Ximeniaceae } & Curupira & $1 / 1$ & Trees \\
\hline & Douradoa & $1 / 1$ & Trees \\
\hline & Ximenia & $3 / 10$ & Shrubs or Trees \\
\hline Total & 33 genera & 269/1118 species & \\
\hline
\end{tabular}

BR spp. = number of species in Brazil; $\mathrm{W}$ spp. $=$ total species in the world.

cies. Sixty-three of these are endemic, and 16 are considered rare (Andrade et al. 2009; Caires 2009a, b; Caires \& Dettke 2010a). Passovia, Psittacanthus and Struthanthus are more diversified in the Brazilian flora when compared to those of other countries in South America. Regarding the geographical distribution of loranthaceous genera in Brazil (Tab. 2), some genera are typically tropical and widespread, e.g., Passovia, Psittacanthus and Struthanthus, whereas others have restricted distributions, e.g., Cladocolea, Gaiadendron, Peristethium, Phthirusa, Oryctanthus, Oryctina and Pusillan- thus. These genera are primarily found in the Amazon and Atlantic Forests, but Pusillanthus and Oryctina also inhabit Caatinga (Caires 2009a; Caires \& Dettke 2010a; Kuijt 2008).

Tripodanthus and Ligaria are typically temperate. Tripodanthus acutifolius is found from Rio Grande do Sul to southern Bahia and is abundant on the trees of the Pampa biome (a grassland vegetation). Tripodanthus acutifolius achieves large stem diameters and often resembles trees. This species can lose its connection with aerial branches and subsequently parasitizes the roots of other tree species. 



Figure 1. Flowers of Brazilian mistletoes (A - Psittacanthus biternatus, B - Psittacanthus robustus, C - Struthanthus flexicaulis), and a bird nest recorded on (D) Psittacanthus plagiophyllus. Photos 'A' and 'D' by RF Fadini; Photo 'B' by GS Teodoro; Photo 'C' by FA Mourão.

Ligaria presents an interesting pattern of disjunction. Ligaria cuneifolia (Ruiz \& Pav.) Tiegh. is widespread in Peru, Bolivia, Argentina, Chile, Uruguay and southern Brazil. A second species, L. teretiflora (Rizzini) Kuijt, is endemic to the municipality of Morro do Chapéu in Bahia State (Kuijt 1990).

The wide morphological diversity in Santalaceae is remarkable. This pantropical group has a close relationship with a clade composed of Amphorogynaceae and Viscaceae, which comprise 11 genera and 61 species. The family includes Eremolepidaceae (Nickrent et al. 2010), a clade containing three genera of New World mistletoes whose members have in the past been assigned to a variety of Santalalean families, such as Loranthaceae, Eremolepidaceae, Santalaceae and Viscaceae. In the Brazilian flora, Santalaceae is represented by four species of Antidaphne and one of Eubrachion (Kuijt 1988) (Tab. 1). Antidaphne is primarily found along the coast of the tropical Atlantic
Forest, though A. amazonensis Rizzini is also found in Amazonia. The other genus is represented by Eubrachion ambiguum (Hook. \& Arn.) Engl., which is rarely found in the Atlantic Forest region but is extremely abundant on trees and shrubs in subtropical grasslands of the Pampa biome.

Viscaceae represents the most divergent group in Santalales. This family comprises seven genera and 400 species, all of which are mistletoes. Dendrophthora and Phoradendron are found in Brazil and include approximately 67 species (Tab. 1). Dendrophthora contains only three species and is patchily distributed over a large area in Brazil, including the Amazonian region, the Cerrado, Caatinga and the Atlantic Forest. Phoradendron is the most widespread genus, occurring throughout northern and southern Brazil (Caires 2009b; Caires \& Dettke 2010b; Kuijt 1961; 2000; 2003) (Tab. 2). Five species of Phoradendron are listed as rare by Caires et al. (2009a), and three species, Phoradendron 
Rafael Arruda, Rodrigo Ferreira Fadini, Lucélia Nobre Carvalho, Kleber Del-Claro, Fabiana Alves Mourão, Claudia Maria Jacobi, Grazielle Sales Teodoro, Eduardo van den Berg, Claudenir Simões Caires and Greta Aline Dettke

Table 2. Distribution of mistletoe genera among Brazilian phytogeographic domains, according to the classification by Veloso et al. (1991) and considered by IBGE (2010).

\begin{tabular}{|c|c|c|c|c|c|c|c|}
\hline \multirow{2}{*}{ Families } & \multirow{2}{*}{ Genera } & \multicolumn{6}{|c|}{ Distribution by Brazilian phytogeographic domain } \\
\hline & & Amazon & Atlantic Forest & Caatinga $^{1}$ & Cerrado $^{2}$ & Pantanal $^{3}$ & Pampa $^{4}$ \\
\hline \multirow[t]{12}{*}{ Loranthaceae } & Cladocolea & $\mathrm{X}$ & $\mathrm{X}$ & & & & \\
\hline & Gaiadendron & $\mathrm{x}$ & & & & & \\
\hline & Phthirusa & & $\mathrm{X}$ & & & & \\
\hline & Ligaria & & & $\mathrm{X}$ & $\mathrm{x}$ & & $\mathrm{X}$ \\
\hline & Oryctanthus & $\mathrm{x}$ & & & & & \\
\hline & Oryctina & & & $\mathrm{X}$ & $\mathrm{X}$ & & \\
\hline & Passovia & $\mathrm{X}$ & $\mathrm{X}$ & $\mathrm{X}$ & $\mathrm{x}$ & $\mathrm{X}$ & \\
\hline & Peristethium & $\mathrm{x}$ & & & & & \\
\hline & Psittacanthus & $\mathrm{X}$ & $\mathrm{X}$ & $\mathrm{X}$ & $\mathrm{X}$ & $\mathrm{X}$ & \\
\hline & Pusillanthus & & $\mathrm{X}$ & $\mathrm{X}$ & & & \\
\hline & Struthanthus & $\mathrm{X}$ & $\mathrm{X}$ & $\mathrm{X}$ & $\mathrm{X}$ & $\mathrm{X}$ & $\mathrm{X}$ \\
\hline & Tripodanthus & & $\mathrm{X}$ & $\mathrm{X}$ & $\mathrm{X}$ & & $\mathrm{X}$ \\
\hline \multirow[t]{2}{*}{ Santalaceae } & Antidaphne & $\mathrm{X}$ & $\mathrm{X}$ & & & & \\
\hline & Eubrachion & & $\mathrm{X}$ & & & & $\mathrm{X}$ \\
\hline \multirow[t]{2}{*}{ Viscaceae } & Dendrophthora & $\mathrm{X}$ & $\mathrm{X}$ & $\mathrm{X}$ & $\mathrm{X}$ & & \\
\hline & Phoradendron & $\mathrm{X}$ & $\mathrm{X}$ & $\mathrm{X}$ & $\mathrm{X}$ & $\mathrm{X}$ & $\mathrm{X}$ \\
\hline
\end{tabular}

${ }^{1}$ Dry forest vegetation, ${ }^{2}$ Savannah vegetation, ${ }^{3}$ Wetland vegetation, ${ }^{4}$ Grassland vegetation

bathyoryctum Eichl., P. crassifolium (Pohl ex DC.) Eichl. and P. piperoides (Kunth) Trel., are abundant on shrubs or trees in most environments.

\section{Mistletoe-host interactions}

An important ecological characteristic of mistletoes is their degree of host specificity. Host specificity is a composite measure of the number of host species mistletoe parasitizes and its relative abundance on these parasitized hosts (Mathiasen et al. 2008). The majority of mistletoe species are host-generalists but still show preference for a particular host species. On the other hand, extreme host specialization is rare in mistletoes. The degree of host specificity can be linked to the scale of observation (Grenfell \& Burns 2009). For example, Fadini (2011) showed in a case study that the mistletoe Psittacanthus plagiophyllus Eichl. is extremely specialized to the native cashew tree (Anacardium occidentale L. - Anacardiaceae) in savannas of Alter do Chão, Pará, Brazil. However, when multiple localities were evaluated, it was found that $P$. plagiophyllus parasitizes at least fourteen different plant species in the Cerrado region (see Caires et al. 2009b; Kuijt 2009) and, thus, should be considered a host-generalist.

Many factors may determine the local degree of host specificity in mistletoes, e.g., the relative abundance of hosts (Norton \& Carpenter 1998), bird perch preferences (Monteiro et al. 1992; Cazetta \& Galetti 2007), branch architecture (Arruda \& Carvalho 2004; Arruda et al. 2006), bark thickness (Sargent 1995) and mistletoe-host compatibility (perhaps determined by chemical, physiological and physical processes at the mistletoe-host interface) (Lamont 1983; López de Buen \& Ornelas 2002; Fadini 2011). Birds provide the initial filter in determining the frequency of seed distribution onto the available hosts, whereas the hosts provide the final filter for mistletoe establishment. Indeed, many mistletoe species germinate anywhere, but can only establish when the appropriate conditions are met in the specific host.

Several studies have indicated that host scarcity hinders the development of parasitism specificity (Janzen 1981; Norton \& Carpenter 1998; Norton \& de Lange 1999). In the neotropical region, this rule fits well for some cases. For example, Arruda et al. (2006) showed that some of the tree species with higher relative abundances in Cerrado were also the most parasitized by the mistletoe Struthanthus polyanthus (Mart. ex Schult. f.) Mart. In the same way, López de Buen \& Ornelas (2002) showed that Liquidambar styraciflua L. (Altingiaceae), the most abundant host tree in a study area in Mexico, was also the most compatible with and parasitized by the mistletoe Psittacanthus schiedeanus (Schltdl. \& Cham.) Blume.

Birds may amplify or counteract the effects of host abundance and host compatibility in determining mistletoehost interactions. For example, López de Buen \& Ornelas (1999) showed that the bird disperser Bombycilla cedrorum (Bombycillidae) perches (and probably deposits mistletoe seeds) preferentially in L. styraciflua, the most abundant and compatible host for P. schiedeanus (see above). A similar mechanism (non-random deposition of mistletoe seeds in the most abundant hosts) was demonstrated for Psittacanthus robustus (Mart.) Mart. in the Brazilian Cerrado (Monteiro et al. 1992). Tersina viridis (Thraupidae) was the primary seed disperser of this species, and it seems to drop or defecate mistletoe seeds preferentially in common trees of the Vochysiaceae family (Monteiro et al. 1992; Teodoro et al. 2010). However, birds may not deposit seeds preferentially on the most common hosts when alternative host 
species offer better perches (Aukema \& Martínez del Rio 2002b; Roxburgh \& Nicolson 2005). These factors (host relative abundance, bird perch preferences and mistletoehost compatibility) establish the foundation for the development of mistletoe-host interactions. Other characteristics, such as bark rugosity, bark thickness and twig inclination, could play important roles in determining the frequency of distribution of established mistletoes on host trees but they are unlikely to affect the range of parasitized hosts (Arruda et al. 2006; Fadini 2011).

While ecological research has been conducted on the host-mistletoe association from a plant-parasite perspective, other less-studied ecological interactions may also be important. We provide two examples: In La Mancha, Mexico, the flowering period of the mistletoe Psittacanthus calyculatus (DC.) G. Don overlaps that of its host Lantana camara L. (Verbenaceae) (Barros et al. 2001). Both species share many secondary pollinators, suggesting an interspecific competition between them. In the woodlands of Arizona, United States, the relationship between the mistletoe Phoradendron juniperinum A. Gray and host Juniperus monosperma (Engelm.) Sarg. (Cupressaceae) is not as intuitive as the above example. Van Omeren \& Whitham (2002) showed that a predictable parasite-host association occurs when analyses are done at a small, individual scale. However, a potential mutualistic relationship arises when the interaction is evaluated at a larger spatial scale. The fruit production of P. juniperinum remains consistent from year to year, which attracts many seed dispersers such as Myadestes townsendii (Turdidae). Consequently, more juniper seeds are dispersed, and more seedlings are produced in areas with high mistletoe density. Indeed, plant-animal interactions can be neutral, positive or negative, depending on several biotic and abiotic factors that can change seasonally (e.g., Bronstein 2009; DelClaro \& Torezan-Silingardi 2009).

In the Chilean desert, the evolution of mistletoe-host interactions has been studied in detail (Medel 2000; Medel et al. 2002). Whereas the cacti species Echinopsis Zucc. (Cactaceae) developed longer and denser spines, rendering mistletoe penetration difficult, the mistletoe Tristerix aphyllus (Miers ex DC.) Barlow \& Wiens (Loranthaceae) evolved an extended radicle to penetrate a larger number of spines. While this association is still being investigated, it seems that the evolution of spine length and structure depends on the host species evaluated and the ecological context (Medel 2000), similar to other host-parasite associations.

\section{Mistletoe pollination and seed dispersal}

Viewing mistletoes as parasites that cause harm to their hosts is only partially valid. Some mistletoe species possess marvelous flowers with a great variety of colors, sizes and shapes (Fig. 1). This variety attracts a diverse array of polli- nators, including hummingbirds for the neotropical species. Loranthaceous mistletoes frequently receive the popular designation of "showy mistletoes". Psittacanthus is one of the most spectacular mistletoes; species of this genus possess large, brilliant and tubular flowers, with inflorescences forming dyads or, more frequently, triads. In the Amazonian savannas Psittacanthus eucalyptifolius (Kunth) G. Don and P. biternatus (Hoffmanns.) G. Don have extended flowering periods ( $c a .6$ to 10 months, R. Reis, unpublished data) that provide resources for many bumblebee and hummingbird species, respectively, all year-round. In the New World, only Aetanthus and Tristerix are comparable to Psittacanthus in their variety of forms and colors (Kuijt 2009) and are also pollinated by hummingbirds. Other mistletoe species, such as those in Phoradendron, Struthanthus and Passovia are not as spectacular, having small and colorless flowers, but they may still be important sources of pollen.

Despite the large number of mistletoe species in the neotropical region, the floral biology and breeding systems of only a few have been studied in detail. Some effort has been dedicated to the Ligaria and Tristerix in the temperate regions of Argentina (Galetto et al. 1990; Rivera et al. 1996; Tadey \& Aizen 2001; Aizen \& Harder 2007) and in the semiarid region of Chile (Gonzáles et al. 2007). Gonzáles et al. (2007) demonstrated that outcrossing could increase the percentage of germination in T. aphyllus, which had never been shown before in mistletoes. Studies of other neotropical mistletoe genera do not offer the same degree of complexity. For example, Azpeitia \& Lara (2006) presents information on the floral morphology, phenology, floral visitation and breeding system of $P$. calyculatus in Mexico. As with other mistletoes species with hermaphroditic flowers (e.g., Tristerix in South America and Alepis in New Zealand), $P$. calyculatus is partially self-compatible, although hummingbirds substantially increase seed production. Phoradendron, Oryctina, Oryctanthus, Struthanthus and Passovia (among others), which have unisexual flowers and are likely insectpollinated, have never been studied in detail.

In Brazil, there have been few studies on mistletoe pollination. Ramos (2002) and Araujo \& Sazima (2003) reported hummingbird visitation in Psittacanthus cordatus (Hoffmanns. ex Schult. f.) G. Don and P. acinarius (Mart.) Mart. (as in P. corynocephalus Eichl.). The gilded hummingbird, Hylocharis chrysura (Trochilidae), was considered the principal pollinator of $P$. cordatus due to its high frequency of visits, and the swallow-tailed hummingbird, Eupetomena macroura (Trochilidae), was correspondingly considered the secondary pollinator (Ramos 2002; Araujo \& Sazima 2003). However, E. macroura was more aggressive in defending $P$. cordatus flowers from $H$. chrysura visits. The flowers of a second species, $P$. acinarius, were tubular and green, exhibited a sweetish and disgusting odor, and presented nocturnal anthesis (Ramos 2002). All of these characteristics are compatible with bat pollination (Fleming et al. 2009). Two bat species were recorded visiting P. acinarius: Glos- 
sophaga soricina (Phyllostomidae) and Phyllostomus discolor (Phyllostomidae), the former being the principal pollinator (Ramos 2002). To our knowledge, this is the first empirical record of chiropterophily for Loranthaceous mistletoes (but see Fleming et al. 2009; Kuijt 2009).

While mistletoe pollination is relatively poorly studied in the Neotropics, frugivory and seed dispersal have received more attention. The global seed dispersers of Viscaceae and Loranthaceae are primarily birds; the only exception is Tristerix corymbosus (L.) Kuijt, which is dispersed by an endemic marsupial (Dromiciops gliroides - Microbiotheriidae) in Argentina (Amico \& Aizen 2000; García et al. 2009). Birds may disperse Viscaceae seeds via endozoocory or epizoocory (Arceuthobium in North America), whereas only endozoochory has been observed for Loranthacae. In contrast, anemochory is restricted to the family Misodendraceae and confined to the Andean region of Argentina and Chile. Even though birds of 17 families and sub-families have been observed consuming fruits of mistletoe species in the New World, Tyrannids and Euphonia/Chlorophonia are the primary seed dispersal agents of Loranthaceae and Viscaceae, respectively (Restrepo et al. 2002).

Different birds consume fruits and seeds in different ways. Seeds can be swallowed whole, with the exocarp removed before the seed is regurgitated, or birds can remove the exocarp before eating the seed and pulp and later defecate the seeds. Bill wiping is also common for bird species that appear to be unaccustomed to a mistletoe diet. There are few detailed studies on mistletoe frugivory and seed dispersal in Brazil. Cazetta \& Galetti (2007) showed that Phoradendron quadrangulare (Kunth) Griseb. (as well as Phoradendron rubrum (L.) Griseb.) is almost exclusively dispersed by Euphonia (Fringillidae), which defecate seeds in clumps on host branches. Guerra \& Marini (2002) showed that Struthanthus concinnus (Mart.) Mart. is dispersed by at least 11 bird species that drop seeds by regurgitation or bill wiping. Monteiro et al. (1992) reported Tersina viridis (Thraupidae) as the main seed disperser of Psittacanthus robustus in the Cerrado, while Fadini et al. (2009) observed Elaenia cristata (Tyrannidae) as the main seed disperser of P. plagiophyllus in Amazonian savannas. In both studies with Psittacanthus, birds regurgitated the seeds. Interaction with birds is of paramount importance for mistletoes seeds because they cannot germinate if their fruits are deposited intact on the host surface (Lamont 1983). Additionally, the method of seed deposition may influence seedling establishment and recruitment. In New Zealand, Kelly et al. (2007) showed that Peraxilla tetrapetala (L. f.) Tiegh. (Loranthaceae) seeds that were experimentally adhered in high densities had a greater chance of attaching to host branches than seeds adhered in low densities. The same pattern was not observed for Phoradendron robustissimum Eichl. in Costa Rica, for which twig size, not seed density, determined the percentage of seedling establishment (Sargent 1995).

\section{Mistletoes as models for testing ecological theory:the metapopulation and epidemiological approaches}

The study of mistletoes offers a promising way to evaluate the mechanisms and processes that create patterns of metapopulation dynamics in plants. According to Overton (1994), mistletoes can be considered metapopulations because they present an intriguing spatial structure. These plants occupy a subdivided habitat: a collection of patches that can be colonized (host trees), areas that will never be colonized (non-host trees) and an inhospitable matrix (area between trees). Because of this spatial structure, mistletoe hosts serve as habitat patches that can be easily monitored, allowing measurement of colonization, recolonization and extinction. In this context, the balance between hemiparasite colonization and extinction rates in the patches characterizes a classic metapopulation dynamics.

Colonization of habitat patches depends on the rates of seed deposition, germination and survival (Aukema \& Martínez del Rio 2002a, c). Such rates are intimately connected to the behavior of the frugivorous bird dispersers. Many of these birds are highly specialized in foraging for fruits (Aukema \& Martínez del Rio 2002a, c). The process of mistletoe extinction is influenced by intrinsic factors, such as the life cycle of the species in question, and extrinsic factors, mainly climate and temperature (García-Franco \& Rico-Gray 1996). In this sense, the patch extinction corresponds to the local extinction of the hemiparasite sub-population.

In some species of hemiparasite, the extinction process is dynamic, such as for Psittacanthus robustus, a hemiparasite that mainly colonizes species of Vochysiaceae in Brazilian savannas (Monteiro et al. 1992; Teodoro et al. 2010). A study conducted in three areas of Brazilian rock-outcrop savannas (cerrado rupestre), in Minas Gerais State, showed that Vochysia thyrsoidea Pohl (Vochysiaceae) is the main host species for $P$. robustus. The species was monitored every six months, and the results suggested that the population of $P$. robustus in each tree of $V$. thyrsoidea (habitat patch) could be considered part of a metapopulation (Teodoro 2010). The model of incident function (Hanski 1994; 1997; Moilanen \& Hanski 1995; 1998) fits well for $P$. robustus because the most important events were related to the rates of colonization and extinction. These processes are related to the probability of local extinction, which depends on population size and the size of the habitat patch. Furthermore, colonization of unoccupied patches is distance-dependent. The distance between habitat patches portrays connectivity. This is important for mistletoe dispersal because the propagule flow among patches depends on the movement patterns of birds.

Some researchers have disagreed with the idea of modeling mistletoes as metapopulations, because migration (=dispersal) and colonization occur on a local scale 
and are highly variable (higher dynamism in mistletoes). Freckleton and Watkinson $(2002 ; 2003)$ suggest that they form a patch structure instead of a metapopulation. If so, an epidemiological approach could be more sensible (Aukema 2003). Otherwise, if the prerequisite of large-scale dynamics is filled, a metapopulation or a source-sink approach for mistletoes could still be useful, as suggested for fragmented landscapes in Australia (Lavorel et al. 1999) and Brazil (Fadini \& Lima 2012).

\section{Effects of mistletoe infections on plant communities}

When mistletoes infest the host vascular system, they can alter growth, reproduction and physiology of the host, significantly reducing their performance (Medel 2000; Aukema 2003; Mourão et al. 2009; Cameron et al. 2009; Bell \& Adams 2011). This effect on host growth and architecture may reduce host photosynthetic efficiency and alter the respiration rates of the plants (Watling \& Press 2001; Cameron et al. 2008). In spite of the direct negative effect on their hosts through the uptake of resources, parasitic plants have an important role in controlling plant populations (Pennings \& Callaway 1996; Marvier 1998; Grewell 2008; Watson $2001 ; 2009)$. The impact of parasitic plants on a community may be widespread, especially if the most parasitized plant species are dominant, which allows inferior competitors to persist via reduced competition (Press \& Phoenix 2005; Grewell 2008). These changes in the host population at the community level occur when the parasitized individuals either die or suffer fitness reduction (Mourão et al. 2009).

An example of a mistletoe that can affect the structure of a plant community is Struthanthus flexicaulis. This species is one of the most common Brazilian mistletoes, with a wide distribution in the Cerrado areas of central Brazil. The influence of $S$. flexicaulis on plant communities was studied in an area of ironstone outcrops at the southern end of the Espinhaço Range in Minas Gerais State, Brazil. These outcrops are characterized by low water retention, shallow soils and high surface temperatures. Despite the stressful edaphic and climatic conditions, the plant community is species-rich (Jacobi et al. 2007). In an area of approximately 9 ha containing 87 vascular species, S. flexicaulis attacked 44 species belonging to 19 families, most of which were perennial dicots. The most parasitized species was Mimosa calodendron Mart. ex Benth. (Fabaceae) (Mourão et al. 2006), a perennial and dominant legume shrub that is frequently used as a perch by birds. Parasitized M. calodendron individuals produce less fruits and lighter seeds than nonparasitized plants, suggesting that their viability may also be reduced. Heavily attacked hosts may show a substantial reduction (75 to 95\%) in photosynthetic area (leaf cover). Therefore, parasitism by S. flexicaulis on M. calodendron, particularly in hydric-stressed environments, may alter $M$. calodendron population structure and dynamics by reducing survival and fecundity rates. In a population of 1,820 individuals, more than $65 \%$ were parasitized, and among these, $20 \%$ were dead, against only two non-parasitized dead plants (Mourão et al. 2009). These negative effects on the legume population may facilitate the establishment of weaker competitors.

Recently, a new avenue of research found the role of mistletoes in nutrient cycling in ecosystems (March \& Watson 2007; 2010). Mistletoes can alter the spatial and temporal distribution of nutrient cycling and enhance the quantity of nutrients available to hosts. Therefore, their presence was considered of great importance in nutrient-poor ecosystems, such as in tropical grasslands and savannas. This has never been studied in the neotropical region and is thus a key priority for future studies.

\section{Conclusions and perspectives}

Mistletoes belong to an intriguing group of plants that have drawn attention because of their harmful effects on host plants and because of their importance as resources for frugivorous animals. Moreover, mistletoes offer a variety of interesting perspectives of study that are practical (e.g., as pests to be controlled), theoretical (e.g., as study models for metapopulation and epidemiological dynamics) and conservational (e.g., as keystone resources and structures to be conserved), which are still poorly investigated.

Despite the fact that Brazil has 10\% of worldwide mistletoe species (Arruda et al. 2009), they are poorly studied and, sometimes, misinterpreted. They have been confounded with lianas (e.g., Rodal et al. 2005; Baptista-Maria et al. 2009), epiphytes (e.g., Rodal et al. 2005; Almeida Jr. et al. 2009), or shrubs (e.g., Sasaki \& Mello-Silva 2008). More than a mere question of semantics, failure to recognize mistletoes as parasites hinders more theoretical advances. For example, as hemiparasites, mistletoes would influence host mortality and their own dynamics, if they were considered lianas or epiphytes, they would not.

The knowledge of mistletoe biology is important in practical and conservation issues. As well as pests, mistletoes are keystone resources and structures. For example, Acanthosyris paulo-alvinii G.M. Barroso (Cervantesiaceae), known as mata-cacau, is a pest of the cacao plantations in southern Bahia (northeast of Brazil). However, it is also a threatened species (MMA 2008). The challenge posed to science and to land managers is to control their populations without leading the species to extinction. Unfortunately, nothing is known about the ecology of this mistletoe that could be used to understand their spread, except for a sparse knowledge of their phytotoxic effects on the growing of cacao plants (Passinho 1993).

Finally, we need to invest time and money in trying to document mistletoe host ranges using standardized methods (Grenfell \& Burns 2009). This basic information could 
help us to understand what determines the use of different host species in a biogeographical scale. Until now, little is known about the mechanisms of host specificity in mistletoes at large spatial scales. In a preliminary study, we noted that only $c a$. of $4 \%$ of mistletoe herbarium sheets have their hosts identified at some level (R.F. Fadini, C.S. Caires \& R. Arruda, unpublished data). Different from the comments of Grenfell \& Burns (2009), we don't have problems with the standardization of studies concerning the host range of mistletoes because we don't have any documentation at all. If we want to understand these large-scale patterns and predict future changes in mistletoe and host populations, we need to increase the number of consistent studies without delay.

\section{Acknowledgments}

We would like thank the many people who helped us in our extensive fieldwork at several field sites in Brazil, especially R. Fernandes for providing unpublished information on the phenology of Psittacanthus spp. in Amazonian savannas. We are indebted to an anonymous referee who reviewed an early version of the manuscript and made extensive language improvements. David Watson kindly gave us a special and inspiring review of the manuscript. We would also like to thank the Brazilian Environmental Agency (ICMBio) for research permits; Universidade Federal de Mato Grosso, Instituto Nacional de Pesquisas da Amazônia, Universidade Federal de Uberlândia, Universidade Federal de Minas Gerais, Universidade Federal de Lavras, Universidade de Brasília and Universidade Federal do Rio Grande do Sul for logistic and financial support; Brazilian Research Council for research grants: CAPES [for a graduate fellowship to CSC and RFF]; CNPq [for graduate fellowships to CSC, FAM, GST and GAD; for financial support to GAD (grant number 471695/2010-6) and to RFF (grant number 479130/2006); for postdoctoral fellowships to RA (grant number 35.0201/2009-9); and for PQ research grant to $\mathrm{KDC}$ and CMJ]; and FAPEMAT [for financial support to RA (grant number 40810/2009)]. This is publication 01 in the Parasitic Plants Research Group and 18 in the NEBAM technical series.

\section{References}

Aizen, M.A. \& Harder, L.D. 2007. Expanding the limits of the pollenlimitation concept: effects of pollen quantity and quality. Ecology 88: $271-281$.

Almeida Jr, E.B.; Olivo, M.A.; Araújo, E.L. \& Zickel, C.S. 2009. Caracterização da vegetação de restinga da RPPN de Maracaípe, $\mathrm{PE}$, Brasil, com base na fisionomia, flora, nutrientes do solo e lençol freático. Acta Botanica Brasilica 23: 36-48.

Amico, G. \& Aizen, M.A. 2000. Mistletoe seed dispersal by a marsupial. Nature 408: 929-930.

Andrade, M.J.G.; Caires, C.S.; Tun-Garrido, J.; Paula, C.H.R. \& Melo, E. 2009. Loranthaceae. Pp. 240-242. In: Giulietti, A.M.; Rapini, A.; Andrade, M.J.G.; Queiroz, L.P. \& Silva, J.M.C. (Orgs.). Catálogo de plantas raras do Brasil. Belo Horizonte, Conservation International.
Araujo, A.C. \& Sazima, M. 2003. The assemblage of flowers visited by hummingbirds in the "capões" of Southern Pantanal, Mato Grosso do Sul, Brazil. Flora 198: 427-435.

Arruda, R \& Carvalho, L.N. 2004. Especificidade de hospedeiros por Struthanthus polyanthus (Loranthaceae) em uma área de Cerrado do Parque Estadual da Serra de Caldas Novas, GO, Brasil. Bioscience Journal 20: 211-214.

Arruda, R.; Carvalho, L.N. \& Del-Claro, K. 2006. Host specificity of a Brazilian mistletoe, Struthanthus aff. polyanthus (Loranthaceae), in cerrado tropical savanna. Flora 201: 127-134.

Arruda, R.; Fadini, R.F.; Mourão, F.A.; Jacobi, C.M. \& Teodoro, G.S. 2009. Natural history and ecology of Neotropical mistletoes. Pp. 133-154. In: Del-Claro, K.; Oliveira, P.S. \& Rico-Gray, V. (Orgs.). Tropical Biology and Conservation Management: Natural history of tropical plants. Oxford, Eolss Publishers Co. Ltd.

Aukema, J.E. 2003. Vectors, viscin and Viscaceae: mistletoes as parasites, mutualists, and resources. Frontiers in Ecology and Environment 1: 212-219.

Aukema, J.E. \& Martínez del Rio, C. 2002a. Mistletoes as parasites and seed-dispersing birds as disease vectors: current understanding, challenges, and opportunities. Pp. 99-110. In: Levey, D.J.; Silva, W.R. \& Galetti, M. (Eds.). Seed dispersal and frugivory: ecology, evolution and conservation. New York, CABI.

Aukema, J.E. \& Martínez del Rio, C. 2002b. Variation in mistletoe seed deposition: effects of intra- and interspecific host characteristics. Ecography 25: 139-144.

Aukema, J.E. \& Martínez del Rio, C. 2002c. Where does a fruit-eating bird deposit mistletoe seeds? Seed deposition patterns and experiment. Ecology 83: 3489-3496.

Azpeitia, F. \& Lara, C. 2006. Reproductive biology and pollination of the parasitic plant Psittacanthus calyculatus (Loranthaceae) in central México. Journal of Torrey Botanical Society 133: 429-438.

Baptista-Maria, V.R.; Rodrigues, R.R.; Damasceno Junior, G.; Maria, F.S. \& Souza, V.C. 2009. Composição florística de florestas estacionais ribeirinhas no Estado de Mato Grosso do Sul, Brasil. Acta Botanica Brasilica 23: 535-548.

Barea, L.P. 2008. Nest-site selection by the Painted Honeyeater (Grantiella picta), a mistletoe specialist. Emu 108: 213-220.

Barros, M.G.; Rico-Gray, V. \& Castelazo, C.D. 2001. Sincronia de floração entre Lantana camara (Verbenaceae) e Psittacanthus calyculatus (Dc.) G. Don (Loranthaceae) ocorrentes nas dunas de La Mancha, Veracruz, México. Acta Botanica Mexicana 57: 1-14.

Bell, T.L. \& Adams, M.A. 2011. Attacks on all fronts: functional relationships between aerial and root parasitic plants and their woody hosts and consequences for ecosystems. Tree Physiology 31: 3-15.

Bronstein, J.L. 2009. The evolution of facilitation and mutualism. Journal of Ecology 97: 1160-1170.

Caires, C.S. 2009a. Loranthaceae. Pp. 312-313. In: Stehmann, J.R.; Forzza, R.C.; Salino, A.; Sobral, M.; Costa, D.P. \& Kamino, L.H.Y. (Eds.). Plantas da Floresta Atlântica. Rio de Janeiro, Jardim Botânico do Rio de Janeiro.

Caires, C.S. 2009b. Santalaceae. Pp. 466-467. In: Stehmann, J.R.; Forzza, R.C.; Salino, A.; Sobral, M.; Costa, D.P. \& Kamino, L.H.Y. (Eds.). Plantas da Floresta Atlântica. Rio de Janeiro, Jardim Botânico do Rio de Janeiro.

Caires, C.S. \& Dettke, G.A. 2010a. Loranthaceae. Pp. 1172-1177. In: Forzza, R.C.; Leitman, P.M.; Costa, A. et al. (Orgs.). Catálogo de plantas e fungos do Brasil, vol. 2. Rio de Janeiro, Andrea Jakobsson Estúdio, Instituto de Pesquisas Jardim Botânico do Rio de Janeiro.

Caires, C.S. \& Dettke, G.A. 2010b. Santalaceae, Pp. 1603-1606. In: Forzza, R.C.; Leitman, P.M.; Costa, A. et al. (Orgs.). Catálogo de plantas e fungos do Brasil, vol. 2. Rio de Janeiro, Andrea Jakobsson Estúdio, Instituto de Pesquisas Jardim Botânico do Rio de Janeiro.

Caires, C.S.; Andrade, M.J.G.; Paula, C.H.R. \& Melo, E. 2009a. Santalaceae. Pp. 364-365. In: Giulietti, A.M.; Rapini, A.; Andrade, M.J.G.; Queiroz, L.P. \& Silva, J.M.C. (Orgs.). Catálogo de plantas raras do Brasil. Belo Horizonte, Conservation International.

Caires, C.S.; Uchôa-Fernandes, M.A.; Nicácio, J \& Strikis, P.C. 2009b. Frugivoria de larvas de Neosilba McAlpine (Diptera, Lonchaeidae) 
sobre Psittacanthus plagiophyllus Eichler (Santalales, Loranthaceae) no sudoeste de Mato Grosso do Sul, Brasil. Revista Brasileira de Entomologia 53: 272-277.

Calder, M. \& Bernardt, P. 1983. The biology of mistletoes. Sidney, Academic Press.

Cameron, D.D.; Geniez, J.M.; Seel, W.E. \& Irving, L.J. 2008. Suppression of host photosynthesis by the parasitic plant Rhinanthus minor. Annals of Botany 101: 573-578.

Cameron, D.D.; White, A. \& Antonovics, J. 2009. Parasite-grass-forb interactions and rock-paper-scissor dynamics: predicting the effects of the parasitic plant Rhinanthus minor on host plant communities. Journal of Ecology 97: 1311-1319.

Carlo, T.A. \& Aukema, J.E. 2005. Female-directed dispersal and facilitation between a tropical mistletoe and a dioecious host. Ecology 86: 3245-3251.

Cazetta, E. \& Galetti, M. 2007. Frugivoria e especifidade por hospedeiros na erva-de-passarinho Phoradendron rubrum (L.) Grised (Viscaceae). Revista Brasileira de Botânica 30: 345-351.

Cooney, S.J.N. \& Watson, D.M. 2008. An experimental approach to understanding the use of mistletoe as a nest substrate for birds: nest predation. Wildlife Research 35: 65-71.

Cooney, S.J.N.; Watson, D.M. \& Young, J. 2006. Mistletoe nesting in Australian birds: a review. Emu 106: 1-12.

Davidar, P. 1987. Fruit structure in two Neotropical mistletoes and its consequences for seed dispersal. Biotropica 19: 137-139.

Del-Claro, K. \& Torezan-Silingardi, H.M. 2009. Insect-plant interactions: new pathways to a better comprehension of ecological communities in Neotropical savannas. Neotropical Entomology 38: 159-164.

Downey, P.O. 1998. An inventory of host species of each aerial mistletoe species (Loranthaceae \& Viscaceae) in Australia. Cunninghamia 5: 685-720.

Fadini, R.F. 2011. Non-overlap of hosts used by three congeneric and sympatric loranthaceous mistletoe species in an Amazonian savanna: host generalization to extreme specialization. Acta Botanica Brasilica 25: 337-345.

Fadini, R.F.; Gonçalves, D.C.M. \& Reis, R.P.F. 2009. Consistency in seeddeposition patterns and the distribution of mistletoes among its host trees in an Amazonian savanna. Australian Journal of Botany 57: 640-646.

Fadini, R.F. \& Lima, A.P. 2012. Fire and host abundance as determinants of the distribution of three congener and sympatric mistletoes in an Amazonian savanna. Biotropica 44: 27-34.

Fleming, T.H.; Geiselman, C. \& Kress, W.J. 2009. The evolution of bat pollination: a phylogenetic perspective. Annals of Botany 104: 1017-1043

Freckleton, R.P. \& Watkinson, A.R. 2002. Large-scale spatial dynamics of plants: metapopulations, regional ensembles and patchy populations. Journal of Ecology 90: 419-434.

Freckleton, R.P. \& Watkinson, A.R. 2003. Are all plant populations metapopulations? Journal of Ecology 91: 321-324.

Forstreuter, W. 1988. Zur Morphologie, Anatomie und Ökologie von Tripodanthus acutifolius (Ruiz \& Pav.) Tiegh. (Loranthaceae). German, Universitat Marburg.

Forstreuter, W. \& Weber, H.C. 1991. Untersuchungen zur morphologie und anatomie des embryos und des keimlings von Tripodanthus acutifolius (Ruiz et Pav.) Tiegh. (Loranthaceae). Flora 185: 153-164.

Galetto, L.; Bernardello, L.M. \& Juliani, H.R. 1990. Acerca del nectario, nectar y visitantes florales en Ligaria cuneifolia (Loranthaceae). Darwiniana 30: 155-161.

García, D.; Rodriguez-Cabal, M.A. \& Amico, G.C. 2009. Seed dispersal by a frugivorous marsupial shapes the spatial scale of a mistletoe population. Journal of Ecology 97: 217-229.

García-Franco, J.G. \& Rico-Gray, V. 1996. Distribution and host specificity in the holoparasite Bdallophyton bambusarum (Rafflesiaceae) in a tropical deciduous forest in Veracruz, Mexico. Biotropica 28: 759-762.

Gonzáles, W.L.; Suárez, L.H. \& Medel, R. 2007. Outcrossing increases infection success in the holoparasitic mistletoe Tristerix aphyllus (Loranthaceae). Evolutionary Ecology 21: 173-183.

Grenfell, M. \& Burns, K.C. 2009. Sampling effects and host ranges in Australian mistletoes. Biotropica 41: 656-658.
Grewell, B.J. 2008. Parasite facilitates plant species coexistence in a coastal wetland. Ecology 89: 1481-1488.

Guerra, T.J.; Camarota, F.; Castro, F.S.; Schwertner, C.F. \& Grazia, J. in press. Trophobiosis between ants and Eurystethus microlobatus Ruckes 1966 (Hemiptera: Heteroptera: Pentatomidae), a cryptic, gregarious and subsocial stinkbug. Journal of Natural History 45(17): 1101-1117.

Guerra, T.J. \& Marini, M. 2002. Bird frugivory on Struthanthus concinnus (Loranthaceae) in Southeastern Brazil. Revista Brasileira de Ornitologia 10: 187-192.

Hanski, I. 1994. A practical model of metapopulation dynamics. Journal of Animal Ecology 63:151-162.

Hanski, I. 1997. Metapopulation dynamics: from concepts and observations to predictive models. Pp. 69-91. In: Hanski, I. \& Gilpin, M.E. (Eds.). Metapopulation biology: ecology, genetics and evolution. London, Academic.

Hiepko, P. 2010. Opiliaceae. Pp. 1344. In: Forzza, R.C.; Leitman, P.M.; Costa, A. et al. (Orgs.). Catálago de plantas e fungos do Brasil, vol. 2. Rio de Janeiro, Andrea Jakobsson Estúdio, Instituto de Pesquisas Jardim Botânico do Rio de Janeiro.

Hudler, G.W.; Oshima, N. \& Hawksworth, F.G. 1979. Bird dissemination of dwarf mistletoe on ponderosa pine in Colorado. American Midland Naturalist 102: 273-280.

IBGE. 2010. Mapa de biomas brasileiros. http://www.ibge.gov.br/home/ geociencias/default_prod.shtm\#MAPAS (acesso em 1/11/2010).

Janzen, D.H. 1981. The peak in North-American Ichneumonid species richness lies between 38 degrees and 42 degrees N. Ecology 62: 532-537.

Jacobi, C.M.; Carmo, F.F.; Vincent, R.C. \& Stehmann, J.R. 2007. Plant communities on ironstones outcrops: a diverse and endangered Brazilian ecosystem. Biodiversity and Conservation 16: 2185-2200.

Kelly, D.; Ladley, J.J. \& Robertson, A.W. 2007. Is the pollen-limited mistletoe Peraxilla tetrapelata (Loranthaceae) also seed limited? Austral Ecology 32: 850-857.

Kuijt, J. 1961. A revision of Dendrophthora (Loranthaceae). Wentia 6: 1-145.

Kuijt, J. 1969. The biology of parasitic plants. Berkeley and Los Angeles, University of California Press.

Kuijt, J. 1988. Monograph of the Eremolepidaceae. Systematic Botany Monographs 18: 1-60.

Kuijt, J. 1990. A second species of Ligaria (Loranthaceae). Brittonia 42 66-69.

Kuijt, J. 2000. An update on the genus Dendrophthora (Viscaceae). Botanische Jahrbücher für Systematik 122: 169-193.

Kuijt, J. 2003. Monograph of Phoradendron (Viscaceae). Systematic Botany Monographs 66: 1-628.

Kuijt, J. 2008. Pusillanthus (Loranthaceae), a new monotypic genus from Venezuela. Novon 18: 370-373.

Kuijt, J. 2009. Monograph of Psittacanthus (Loranthaceae). Systematic Botany Monographs 86: 1-361.

Lamont, B.B. 1983. Germination of mistletoes. Pp. 129-141. In: Calder, M. \& Bernhardt, P. (Eds.). The biology of mistletoes. Sydney, Academic Press.

Lavorel, S.; Stafford Smith, M. \& Reid, N. 1999. Spread of mistletoes (Amyema preissii) in fragmented Australian woodlands: a simulation study. Landscape Ecology 14: 147-160.

López de Buen, L. \& Ornelas, J.F. 1999. Frugivorous birds, host selection and the mistletoe Psittacanthus schiedeanus, in central Veracruz, Mexico. Journal of Tropical Ecology 15: 329-340.

López de Buen, L. \& Ornelas, J.F. 2002. Host compatibility of the cloud forest mistletoe Psittacanthus schiedeanus (Loranthaceae) in central Veracruz, Mexico. American Journal of Botany 89: 95-102.

March, W.A. \& Watson, D.M. 2007. Parasites boost productivity: effects of mistletoe on litterfall dynamics in a temperate Australian forest. Oecologia 154: 339-347.

March, W.A. \& Watson, D.M. 2010. The contribution of mistletoes to nutrient returns: evidence for a critical role in nutrient cycling. Austral Ecology 35: 713-721.

Mathiasen, R.L.; Nickrent, D.L.; Shaw, D.C. \& Watson, D.M. 2008. Mistletoes: pathology, systematics, ecology, and management. Plant Disease 92: 988-1006. 
Marvier, M.A. 1998. Parasite impacts on host communities: plant parasitism in a California Coastal Prairie. Ecology 79: 2616-2623.

Medel, R. 2000. Assessment of parasite-mediated selection in a hostparasite system in plants. Ecology 81: 1554-1564.

Medel, R.; Botto-Mahan, C.; Smith-Ramírez, C.; Méndez, M.A.; Ossa, C.G.; Caputo, L. \& Gonzáles, W.L. 2002. Historia natural cuantitativa de una relación parásito-hospedero: el sistema Tristerix-cactáceas en Chile semiárido. Revista Chilena de Historia Natural 75: 127-140.

MMA 2008. Lista oficial das espécies da flora brasileira ameaçadas de extinção. Instrução Normativa de 06 de 23 de Setembro de 2008.

Moilanen, A. \& Hanski, I. 1995. Habitat destruction and competitive coexistence in a spatially realistic metapopulation model. Journal of Animal Ecology 64:141-144.

Moilanen, A. \& Hanski, I. 1998. Metapopulational dynamics: effects of habitat quality and landscape structure. Ecology 79: 2503-2515.

Monteiro, R.F.; Martins, R.P. \& Yamamoto, K. 1992. Host specificity and seed dispersal of Psittacanthus robustus (Loranthaceae) in south-east Brazil. Journal of Tropical Ecology 8: 307-314.

Mourão, F.A.; Carmo, F.F.; Ratton, P. \& Jacobi, C.M. 2006. Hospedeiras da hemiparasita Struthanthus flexicaulis (Mart.) Mart. (Loranthaceae) em campos rupestres ferruginosos, Quadrilátero Ferrífero, MG. Lundiana 7: 103-110.

Mourão, F.A.; Jacobi, C.M.; Figueira, J.E.C. \& Batista, E.K.L. 2009. Effects of the parasitism of Struthanthus flexicaulis (Mart.) Mart. (Loranthaceae) on the fitness of Mimosa calodendron Mart. (Fabaceae), an endemic shrub from rupestrian fields over ironstone outcrops, Minas Gerais State, Brazil. Acta Botanica Brasilica 23: 820-825.

Nickrent, D.L.; Malécot, V.; Vidal-Russell, R. \& Der, J.P. 2010. A revised classification of Santalales. Taxon 59: 538-558.

Norton, D.A. \& Carpenter, M.A. 1998. Mistletoes as parasites: host specificity and speciation. Trends in Ecology and Evolution 13: 101-105.

Norton, D.A. \& de Lange, P.J. 1999. Host specificity in parasitic mistletoes (Loranthaceae) in New Zealand. Functional Ecology 13: 552-559.

Norton, D.A. \& Reid, N. 1997. Lessons in ecosystem management from management of threatened and pest loranthaceous mistletoes in New Zealand and Australia. Conservation Biology 11: 759-769.

Overton, J.M. 1994. Dispersal and infection in mistletoe metapopulations. Journal of Ecology 82: 711-723.

Passinho, H.C.R. 1993. Efeitos de extratos de mata-cacau (Acanthosyris paulo-alvinii Barroso) na germinação e crescimento de plântulas de cacau (Theobroma cacao L.) e na germinação de milho (Zea mays L.) e feijão (Phaseolus vulgaris L.). MSc Dissertation. Universidade Federal da Bahia, Bahia, Brazil.

Penning, S.C. \& Callaway, R.M. 1996. Impact of a parasitic plant on the structure and dynamics of salt marsh vegetation. Ecology 77: 14101419.

Press, M.C. \& Graves, J.D. 1995. Parasitic plants. London, Chapman and Hall.

Press, M.C. \& Phoenix, G.K. 2005. Impacts of parasitic plants on natural communities. New Phytologist 166: 737-751.

Ramos, L. 2002. Polinização por beija-flores e morcegos em duas espécies de Psittacanthus (Loranthaceae) no Pantanal Sul-Mato-Grossense. MSc Dissertation, Universidade Federal de Mato Grosso do Sul, Mato Grosso do Sul, Brazil.

Restrepo, C.; Sargent, S.; Levey, D.J. \& Watson, D.M. 2002. The role of vertebrates in the diversification of new world mistletoes. Pp. 83-98.
In: Levey, D.J.; Silva, W.R. \& Galetti, M. (Eds.). Seed dispersal and frugivory: ecology, evolution and conservation. New York, CABI.

Rivera, G.L.; Galetto, L. \& Bernardello, L.M. 1996. Nectar secretion pattern, removal effects, and breeding system of Ligaria cuneifolia (Loranthaceae). Canadian Journal of Botany 74: 1996-2001.

Rodal, M.J.N.; Sales, M.F.; Silva, M.J. \& Silva, A.G. 2005. Flora de um Brejo de Altitude na escarpa oriental do planalto da Borborema, PE, Brasil. Acta Botanica Brasilica 19: 843-858.

Rossi, L. 2010. Olacaceae. Pp. 1339-1341. In: Forzza, R.C.; Leitman, P.M.; Costa, A. et al. (Orgs.). Catálago de plantas e fungos do Brasil, vol. 2. Rio de Janeiro, Andrea Jakobsson Estúdio, Instituto de Pesquisas Jardim Botânico do Rio de Janeiro.

Roxburgh, L. \& Nicolson, S.W. 2005. Patterns of host use in two African mistletoes: the importance of mistletoe-host compatibility and avian disperser behaviour. Functional Ecology 19: 865-873.

Sargent, S. 1995. Seed fate in a tropical mistletoe: the importance of host twig size. Functional Ecology 9: 197-204.

Sasaki, D. \& Mello-Silva, R. 2008. Levantamento florístico no cerrado de Pedregulho, SP, Brasil. Acta Botanica Brasilica 22: 187-202.

Tadey, M. \& Aizen, M.A. 2001. Why do flowers of a hummingbirdpollinated mistletoe face down? Functional Ecology 15: 782-790.

Teodoro, G.S. 2010. Estrutura e dinâmica metapopulacional da ervade-passarinho Psittacanthus robustus Mart. (Loranthaceae) em manchas de habitat em três áreas de cerrado. MSc Dissertation, Universidade Federal de Lavras, Minas Gerais, Brazil.

Teodoro, G.S.; van den Berg, E.; Santos, M.C.N. \& Coelho, F.F. 2010. How does a Psittacanthus robustus Mart. population structure relate to a Vochysia thyrsoidea Pohl. host population? Flora 205: 797-801.

Thomson, V.E. \& Mahall, B.E. 1983. Host specificity by a mistletoe, Phoradendron villosum (Nutt.) Nutt. subsp. villosum, on three oak species in California. Botanical Gazette 144: 124-131.

van Ommeren, R.J. \& Whitham, T.G. 2002. Changes in interactions between juniper and mistletoe mediated by shared avian frugivores: parasitism to potential mutualism. Oecologia 130: 281-288.

Veloso, H.P.; Rangel Filho, A.L.R. \& Lima, J.C.A. 1991. Classificação da vegetação brasileira, adaptada a um sistema universal. Rio de Janeiro, IBGE.

Venturelli, M. 1981. Estudos sobre Struthanthus vulgaris Mart.: anatomia do fruto e semente e aspectos de germinação, crescimento e desenvolvimento. Revista Brasileira de Botânica 4: 131-147.

Venturelli, M. 1984a. Estudos sobre Struthanthus vulgaris Mart.: aspectos anatômicos de raiz adventícia, caule e folha. Revista Brasileira de Botânica 7: 79-89.

Venturelli, M. 1984b. Estudos embriológicos em Loranthaceae: Struthanthus flexicaulis Mart. Revista Brasileira de Botânica 7: 107-119.

Venturelli, M. \& Kraus, J.E. 1989. Morphological and anatomical aspects of the primary haustorium of Struthanthus vulgaris Mart. (Loranthaceae) in vitro. Revista Brasileira de Botânica 12: 17-22.

Vidal-Russel, R. \& Nickrent, D.L. 2008. The first mistletoes: origins of aerial parasitism in Santalales. Molecular Phylogenetics and Evolution 47: 523-537.

Watling, J.R. \& Press, M.C. 2001. Impacts of infection by parasitic angiosperms on host photosynthesis. Plant Biology 3: 244-250.

Watson, D.A. 2001. Mistletoe - a keystone resource in forests and woodlands worldwide. Annual Review of Ecology and Systematics 32: 219-249.

Watson, D.A. 2009. Parasitic plants as facilitators: more Dryad than Dracula? Journal of Ecology 97: 1151-1159. 